\title{
PENGARUH MODEL PBL DENGAN MEDIA GOOGLE CLASSROOM TERHADAP AKTIVITAS DAN HASIL BELAJAR SISWA
}

\author{
Nurridha Rahmania Yusuf'), Singgih Bektiarso ${ }^{1)}$, Sudarti1) \\ 1)Program Studi Pendidikan Fisika, FKIP, Universitas Jember, Jember, Jawa Timur, Indonesia \\ Corresponding author : Nurridha Rahmania Yusuf \\ E-mail : nurridhay@gmail.com
}

Diterima 28 September 2020, Direvisi 17 Oktober 2020, Disetujui 19 Oktober 2020

\begin{abstract}
ABSTRAK
Penelitian ini bertujuan untuk mengkaji pengaruh model problem based learning dengan media google classroom terhadap aktivitas dan hasil belajar siswa pada materi gelombang bunyi di SMAN Pakusari. Jenis penelitian ini adalah penelitian eksperimen dengan pretest-posttest control design. Pengumpulan data hasil belajar siswa dari nilai pretest dan posttest, serta aktivitas belajar siswa dari hasil observasi selama kegiatan pembelajaran. Penelitian ini menghasilkan data rata-rata aktivitas belajar di kelas eksperimen lebih besar daripada kelas kontrol, yaitu $66,35 \%$ dan $55,31 \%$, dan juga rata-rata hasil belajar siswa dari posttest pada kelas eksperimen lebih besar daripada kelas kontrol, yaitu 60 dan 50 . Analisis data menggunakan uji T-Test yang menghasilkan nilai signifikansi aktivitas belajar dan hasil belajar kurang dari 0,05, yaitu 0,017 dan 0,002. Berdasarkan analisis tersebut, dapat disimpulkan bahwa pembelajaran menggunakan model PBL dengan media google classroom berpengaruh signifikan terhadap aktivitas dan hasil belajar siswa pada materi gelombang bunyi di SMAN Pakusari.
\end{abstract}

Kata kunci: model PBL dengan media google classroom; aktivitas belajar siswa; hasil belajar siswa.

\begin{abstract}
This research aims to assess the effect of problem based learning model with google classroom media on activity and student learning outcomes of sound wave material at Pakusari senior high school. This type of research is experimental research with pretest-posttest control design. Data collection of student learning outcomes are pretest and posttest scores, and student learning activities is from observation results during learning. The result of this research are the average of learning activities in experimental class greater than control class, i.e $66,35 \%$ and $55,31 \%$, and also the average of student learning outcomes from posttest in experimental class greater than control class, i.e 60 and 50. Data analysis using T-test which results in significance value of learning activity and learning outcomes of less than 0,05 , i.e 0,017 and 0,002 . Based on analysis, it can be concluded that learning by problem based learning model with google classroom media has significant effect on student's activity and learning outcomes on sound wave material at Pakusari senior high school.
\end{abstract}

Keywords: PBL model with google classroom media; learning activities; learning outcomes.

\section{PENDAHULUAN}

Undang-Undang Republik Indonesia Nomor 20 Tahun 2003 pasal 1 ayat 1 , yang merupakan landasan formal tentang pendidikan di Indonesia, menjelaskan bahwa pendidikan merupakan suatu usaha terencana untuk mewujudkan suasana belajar dan proses pembelajaran yang dapat mengembangkan potensi dalam diri siswa, serta memiliki kekuatan spiritual keagamaan, akhlak mulia, pengendalian diri, kepribadian, kecerdasan, dan keterampilan yang berguna bagi diri sendiri, masyarakat, dan bangsa (Nofrion, 2016: 41). Pendidikan adalah usaha secara sadar dalam pembelajaran yang meliputi spiritual, akhlak mulia, pengetahuan, keterampilan, dan kebiasaan yang disampaikan melalui pengajaran, pelatihan, atau penelitian, untuk membangun potensi peserta didik.

Ujian Nasional (UN) merupakan sistem evaluasi standar pendidikan dasar dan menengah secara nasional. Kemendikbud menyebutkan dalam tulisannya tentang "Perubahan Kebijakan Ujian Nasional", bahwa UN bertujuan sebagai persamaan mutu tingkat pendidikan antar daerah di Indonesia, dasar seleksi untuk ke jenjang pendidikan berikutnya, dan meningkatkan mutu pendidikan. Untuk jenjang SMA, mata pelajaran yang diujikan antara lain bahasa Indonesia, bahasa inggris, matematika, dan mata pelajaran karakteristik penjurusan. Jenjang SMA pada jurusan IPA, mata pelajaran karakteristik penjurusannya yaitu; fisika, kimia, dan biologi. Kemendikbud 
mencatat rata-rata nilai UN fisika, biologi, dan kimia, dalam laporan hasil ujian nasional pada tahun 2019 di seluruh Indonesia secara berurutan, yaitu: 46,352; 50,449; dan 50,831. Sedangkan untuk di Kabupaten Jember sendiri, rata-rata nilai UN fisika, biologi, dan kimia pada jenjang SMA/sederajat pada tahun 2019 secara berurutan, antara lain: 44,73; 51,97; dan 53,87. Berdasarkan data ini, dapat diketahui bahwa nilai UN fisika memiliki rata-rata paling rendah dari ketiga mata pelajaran khusus penjurusan IPA yang diujikan.

Fisika dapat digolongkan dalam suatu ilmu yang berdasarkan pengumpulan dari kejadian - kejadian khusus di alam (Argaw et al., 2017: 858). Fisika sebenarnya dapat ditemukan dalam kehidupan sehari-hari di sekitar kita. Contoh yang dapat diambil diantaranya: manusia dapat mendengar suara radio yang berbunyi dan suara-suara tertentu pada frekuensi tertentu. Oleh karena itu, pembelajaran fisika sebaiknya dilakukan dengan cara pembelajaran bermakna atau melalui fenomena sehari-hari.

Pembelajaran adalah proses interaksi peserta didik dengan pendidik dan sumber belajar dalam suatu lingkungan belajar (Suardi, 2018: 6). Pembelajaran yang efektif merupakan pembelajaran yang dilakukan siswa dengan aktivitas belajar sendiri. Di dalam kelas, proses pembelajaran adalah suatu aktivitas mentransformasikan pengetahuan, sikap, dan keterampilan. Aktivitas adalah prinsip yang sangat penting dalam suatu interaksi belajar mengajar. Aktivitas belajar ini meliputi aktivitas fisik dan mental. Maka, aktivitas belajar siswa merupakan serangkaian kegiatan fisik dan mental yang saling berkaitan dan menciptakan suasana belajar yang optimal.

Hasil belajar merupakan serangkaian evaluasi dari proses belajar untuk menandakan bahwa kegiatan pembelajaran yang dilakukan sudah efisien, dengan ditandai adanya perubahan tingkah laku, kemampuan, dan pengetahuan siswa. Hasil belajar meliputi ranah kognitif, afektif, dan psikomotorik. Hasil belajar juga dapat dikatakan merupakan serangkaian evaluasi terhadap proses belajar, dimana dalam mengevaluasi memerlukan suatu alat. Alat yang paling efektif untuk penilaian hasil belajar adalah menggunakan tes. Karena dengan tes dapat diketahui tingkat kemampuan siswa dalam memahami materi yang disampaikan guru. Tes dapat berupa tes subyektif ataupun tes obyektif.

Beberapa penelitian yang relevan menunjukkan adanya peningkatan hasil belajar siswa, ada yang menyebutkan dari segi kognitif dan ada yang menyebutkan dari segi kognitif, afektif, dan psikomotorik. Penelitian pertama dari Argaw et al. (2017: 864), dalam penelitiannya menyatakan bahwa proses pembelajaran menggunakan model problem based learning (PBL) memiliki pengaruh terhadap hasil belajar. Dibuktikan dengan nilai rata-rata post-tes kelas kontrol dan eksperimen adalah 38,54 dan 50,25. Sebelum diterapkan model PBL pada kelas eksperimen, nilai pre-tes kelas kontrol dan eksperimen yaitu 22,20 dan 22,25. Artinya, dari nilai post-tes, didapatkan bahwa kelas eksperimen mengalami peningkatan nilai lebih tinggi dari kelas kontrol. Oleh karena itu, dapat diketahui bahwa terdapat peningkatan yang cukup tinggi dari hasil belajar siswa yang menggunakan model PBL. Model problem based learning (PBL) membuat siswa dapat bereksplorasi dalam memecahkan masalah yang diberikan, baik dipecahkan secara individu maupun kelompok. Sehingga, model PBL adalah model pembelajaran alternatif yang dapat meningkatkan prestasi siswa dan meningkatkan kemampuan bersosial siswa.

Penelitian kedua dari Himah et al. (2015: 264-266) menyatakan bahwa model PBL dengan pictorial riddle berpengaruh terhadap hasil belajar dan aktivitas belajar siswa. Nilai post-test kelas eksperimen lebih besar daripada kelas kontrol, yaitu 71,54 dan 60,32. Aktivitas belajar dibuktikan dengan rata-rata presentase seluruh pembelajaran pada kelas eksperimen $82,17 \%$ dan tergolong aktif.

Penelitian ketiga dari Putra et al. (2016: 131-133) yang juga menyatakan bahwa model PBL dapat meningkatkan hasil belajar kognitif siswa. Skor rata-rata hasil belajar kognitif siswa kelas eksperimen adalah 72,64, sedangkan skor rata-rata kognitif siswa kelas kontrol adalah 65,24. Penelitian ini juga menyatakan bahwa alasan model PBL dapat meningkatkan hasil belajar siswa, karena permasalahan yang diberikan berdasarkan masalah fisika yang mudah ditemui di kehidupan sehari-hari siswa.

Penelitian keempat dari Farisi \& Hamid (2017: 285-286), yang dalam penelitiannya juga mengemukakan bahwa model problem based learning ( $\mathrm{PBL})$ mampu meningkatkan hasil belajar siswa. Post-test yang diberikan kepada siswa menunjukkan bahwa kelas eksperimen dan kelas kontrol memiliki nilai yang berbeda, dimana kelas eksperimen mendapatkan ratarata nilai tes akhir sebesar 71,318 dan kelas kontrol memiliki rata-rata nilai post-test sebesar 57,1. Data post-test tersebut menunjukkan bahwa model PBL juga memiliki pengaruh dalam meningkatkan kemampuan berpikir kritis untuk meningkatkan hasil belajar siswa pada materi suhu dan kalor. LKPD digunakan dalam penelitiannya untuk membantu siswa dalam menyelesaikan permasalahan. Faris, et al 
menyebutkan alasan model PBL dapat meningkatkan hasil belajar siswa, karena model tersebut dalam proses pembelajarannya bepusat pada siswa sehingga memberikan pengalaman secara langsung kepada siswa.

Berdasarkan apa yang sudah dijabarkan sebelumnya, model problem based learning (PBL) adalah model pembelajaran yang diidentifikasi siswa tidak sebagai penerima pasif pengetahuan, tetapi sebagai pemecah masalah yang bisa mengembangkan pengetahuan. Dalam model PBL, siswa tidak hanya harus memahami konsep yang relevan dengan masalah yang menjadi pusat perhatian, tetapi juga memperoleh pengalaman belajar yang berhubungan dengan keterampilan menerapkan metode ilmiah dalam memecahkan masalah dan menumbuhkan pola berpikir kritis. Model ini merupakan inovasi pembelajaran yang dirancang untuk membantu peserta didik memahami teori secara mendalam melalui pengalaman belajar praktik empirik.

Media pembelajaran adalah segala sesuatu yang berguna untuk menyampaikan dan menyalurkan pesan secara terencana, sehingga terjadi lingkungan belajar yang kondusif dan penerima pembelajaran dapat melakukan proses pembelajaran dengan efektif dan efisien. Salah satu media pembeljaran yang dapat digunakan adalah google classroom. Google classroom adalah aplikasi dari google berupa ruang kelas online atau virtual yang dapat membantu guru dalam meningkatkan interaksi dan komunikasinya dengan siswanya. Gunawan \& Sunarman (2017: 345-346) dalam penelitiannya mengemukakan bahwa google classrom mampu meningkatkan keefektifan dalam pembelajaran. Google classroom juga memiliki ketertarikan dan keunikan sendiri bagi siswa. Siswa dapat melakukan pembelajaran tanpa terikat waktu, dimana siswa dapat menanyakan materi yang belum dipahami melalui google classroom.

Pembelajaran model PBL dimulai dengan pemberian masalah, kemudian siswa mencari tahu dan memperdalam pengetahuannya untuk memecahkan masalah tersebut. Dalam PBL ini, masalah adalah fokus pembelajaran yang dapat diselesaikan melalui kerja kelompok, sehingga memberikan pengalaman-pengalaman belajar yang beragam pada siswa, seperti kerjasama dan interaksi dalam kelompok. Untuk lebih meningkatkan aktivitas belajar siswa, diperlukan kolaborasi yang tepat antara model pembelajaran dan media pembelajaran yang digunakan guru dalam menyampaikan materi fisika. Dalam hal ini, penulis menggunakan media google classroom untuk mendukung model PBL dengan harapan mampu meningkatkan aktivitas dan hasil belajar siswa melalui pembelajaran yang menyenangkan dalam proses belajar siswa.

Model pembelajaran problem based learning memiliki beberapa kekurangan, salah satunya dalam hal keefektifan selama proses pembelajaran. Pada umumnya, model PBL ini memerlukan waktu yang cukup banyak, sehingga pembelajaran di kelas biasanya tidak cukup waktunya. Peneliti memilih media google classroom untuk mengatasi masalah keefektifan selama pembelajaran. Hal ini berdasarkan penelitian sebelumnya yang sudah membuktikan bahwa google classroom dapat membantu guru membuat siswa lebih tepat waktu dalam pengumpulan tugas. Peneliti juga berharap media tersebut dapat membantu mengatasi masalah keefektifan waktu pembelajaran dengan menggunakan model PBL di kelas. Google classroom juga memiliki ketertarikan dan keunikan sendiri, maka penulis berharap media tersebut dapat mengatasi kebosanan siswa dan diharapkan juga mampu meningkatkan aktivitas belajar siswa selama pembelajaran di kelas.

Dalam penelitian sebelumnya yang dilakukan oleh Argaw A.S, et al (2017), Himah, et al (2015), Putra, et al (2017), dan Farisi, et al (2017), yang membahas tentang pengaruhnya model pembelajaran berbasis masalah terhadap peningkatan hasil belajar dan penelitian yang dilakukan oleh Gunawan dan Sunarman (2018) yang meniliti tentang pengembangan google classroom dalam keterampilan pemecahan masalah dan keefektifan pembelajaran, ditemukan bahwa masih terdapat celah dalam penelitian yang mereka lakukan. Sehingga diperlukan penelitian berjudul "Pengaruh Model PBL dengan Media Google Classroom terhadap Aktivitas dan Hasil Belajar Siswa".

\section{METODE PENELITIAN}

Jenis penelitian ini adalah true experiment. Desain penelitian yang digunakan adalah pretest-postest control design, artinya sebelum diberi perlakuan, kedua sampel penelitian diberikan pretest sebagai tes awal untuk mengukur kembali kemampuan awal siswa yang dianggap hampir sama. Kemudian, kelas eksperimen diberi perlakuan berupa pembelajaran model PBL dengan media google classroom dan kelas kontrol menggunakan CTL. Setelah diberikan perlakuan, kedua kelas diberi posttest untuk mengukur kemampuan akhir siswa.

Penelitian ini dilaksanakan di SMA Negeri Pakusari pada semester genap tahun ajaran 2019/2020, mulai tanggal 6 Februari 
sampai dengan 21 Februari 2020. Materi yang dipilih adalah gelombang bunyi. Tempat penelitian tersebut ditentukan menggunakan purposive sampling area. Sampel penelitian ditentukan setelah uji homogenitas menggunakan aplikasi SPSS melalui One Way ANNOVA. Uji tersebut menggunakan nilai materi sebelumnya (gelombang mekanik) pada semua populasi, yaitu kelas XI IPA. Penentuan sampel dipilih dengan cara cluster random sampling (sampel dipilih secara acak). Penentuan sampel tersebut menghasilkan dua sampel, yaitu kelas XI IPA 3 sebagai kelas eksperimen dan kelas XI IPA 5 sebagai kelas kontrol.

Metode pengumpulan data dalam penelitian ini adalah tes, wawancara, observasi, dan dokumentasi. Teknik analisis data aktivitas belajar dan hasil belajar siswa, diuji menggunakan uji Independent sample t-test pada SPSS, untuk mengetahui ada tidaknya perbedaan yang signifikan antara hasil belajar siswa pada kelas eksperimen dan kelas kontrol, begitu juga dengan aktivitas belajar siswa. Data yang digunakan untuk menganalisis hasil belajar siswa adalah nilai post-test. Pengolahan nilai untuk mendapatkan data aktivitas belajar siswa selama tiga kali pembelajaran diperoleh menggunakan persamaan berikut:

Hasil skor $=\frac{\sum \text { skor perolehan tiap siswa }}{\sum \text { skor maksimal }} \times 100 \%$

Sedangkan pengolahan nilai untuk mendapatkan data nilai pretest dan hasil belajar siswa, digunakan persamaan berikut:

Hasil skor $=\frac{\sum \text { skor perolehan tiap siswa }}{\sum \text { skor maksimal }}$

\section{HASIL DAN PEMBAHASAN}

Penelitian ini bertujuan untuk mengkaji pengaruh model problem based learning (PBL) dengan media google classroom terhadap aktivitas belajar siswa selama pembelajaran dan hasil belajar siswa setelah pembelajaran pada materi gelombang bunyi. Berdasarkan penelitian yang telah dilakukan diperoleh data aktivitas belajar dan hasil belajar siswa. Tujuan pertama adalah aktivitas belajar siswa selama tiga kali pembelajaran yang diperoleh melalui observasi dan pengisian data pada lembar observasi. Indikator penilaian yang digunakan antara lain: tanggungjawab, keaktifan, kepedulian, semangat belajar, dan kecakapan komunikasi siswa. Berikut merupakan data aktivitas belajar siswa berupa rata-rata presentase aktivitas belajar siswa pada kelas eksperimen dan kelas kontrol dapat dilihat pada Tabel 1 berikut.
Tabel 1. Nilai Aktivitas Belajar Siswa

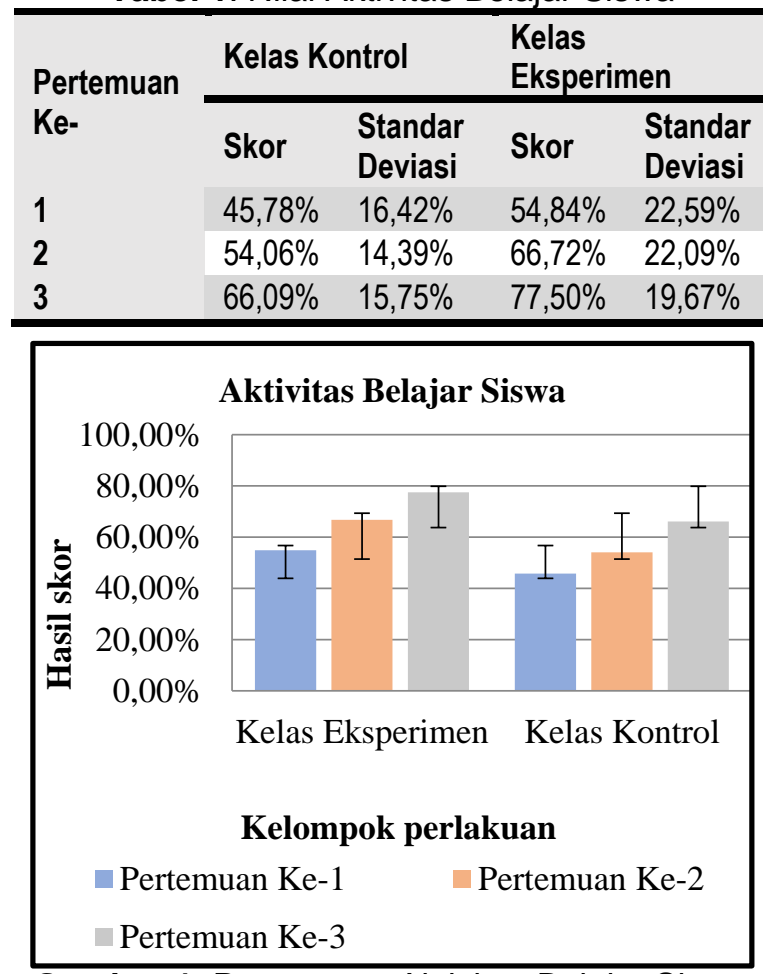

Gambar 1. Persentase Aktivitas Belajar Siswa Tiap Pertemuan

Berdasarkan tabel 1 dan gambar 1 , dapat diketahui bahwa rata-rata skor aktivitas belajar kelas eksperimen lebih besar daripada kelas kontrol. Adapun hasil anlisis independent sample T-test didapatkan nilai Sig. (2-tailed) pada equal variance assumed adalah 0,017. Nilai signifikansi tersebut kurang dari 0,05 dan berdasarkan pedoman pengambilan keputusan, maka $\mathrm{H}_{0}$ ditolak dan $\mathrm{H}_{a}$ diterima. Artinya, terdapat perbedaan nilai rata-rata aktivitas belajar siswa pada kelas eksperimen dan kelas kontrol.

Berdasarkan uraian diatas, dapat disimpulkan bahwa ada perbedaan yang signifikan antara aktivitas belajar siswa yang menggunakan model problem based learning (PBL) dengan media google classroom dengan model pembelajaran yang biasa digunakan di SMAN Pakusari (model pembelajaran CTL). $\mathrm{Hal}$ ini sesuai dengan penelitian Himah et al. (2015: 264-266) yang menyatakan bahwa model PBL dapat meningkatkan aktivitas belajar siswa. Adanya perbedaan yang signifikan antara aktivitas belajar siswa kelas eksperimen dengan kelas kontrol dipengaruhi oleh beberapa faktor. Faktor-faktor tersebut meliputi, siswa yang dituntut menjadi aktif selama pembelajaran dengan bantuan media google classroom yang menyenangkan sehingga mendorong semangat belajar dan kecakapan komunikasi siswa, serta membuat siswa menjadi mandiri sehingga memiliki 
tanggungjawab dan rasa peduli dalam kelompok belajar. Penelitian Putra et al. (2016: 131-133) juga menyatakan bahwa model PBL dapat meningkatkan kemampuan proses sains, yang salah satunya sesuai dengan faktor-faktor yang sudah disebutkan sebelumnya, yaitu kecakapan komunikasi siswa.

Tujuan kedua adalah hasil belajar siswa setelah diberi perlakuan model pembelajaran $\mathrm{PBL}$ dengan media google classroom yang diperoleh dari hasil post-test. Nilai pre-test digunakan untuk mengetahui dan mengecek kembali kemampuan awal hasil belajar siswa pada kelas eksperimen dan kelas kontrol. Berikut merupakan data hasil belajar siswa yang berupa rata-rata nilai pre-test dan nilai post-test pada kedua kelas dapat dilihat pada Tabel 2 berikut.

Tabel 2. Nilai Pretest dan Posttest Siswa

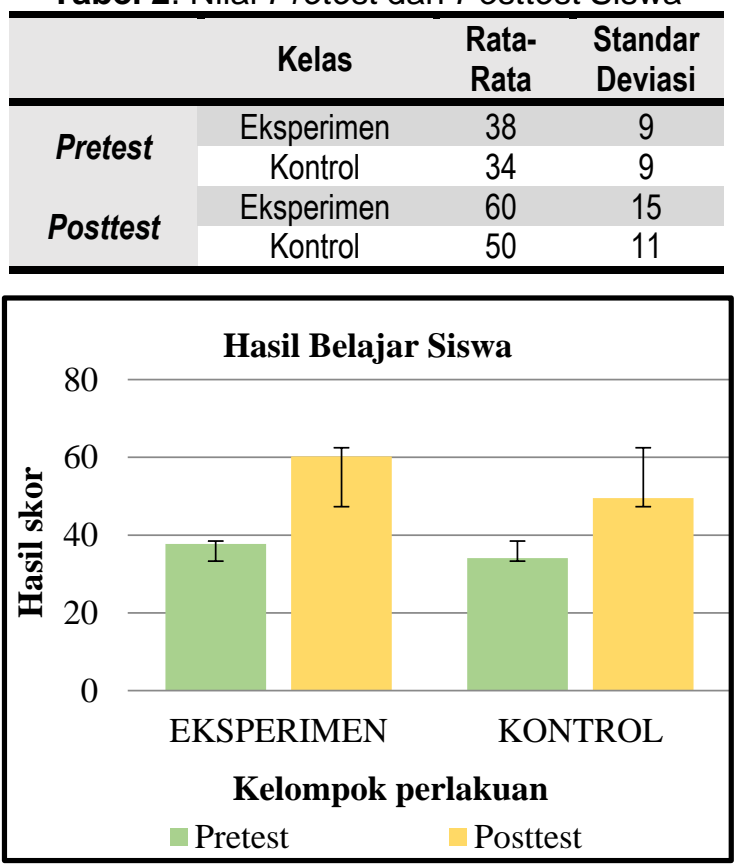

Gambar 2. Nilai Pretest dan Posttest pada Kelas Eksperimen dan Kontrol

Berdasarkan tabel 2 dan gambar 2, dapat diketahui bahwa rata-rata nilai pre-test pada kelas eksperimen dan kelas kontrol hampir sama. Artinya kemampuan awal siswa pada kedua kelas tidak jauh berbeda. Setelah diberi perlakuan yang berbeda pada kedua kelas, dengan kelas eksperimen diberlakukan model problem based learning dengan media google classroom dan kelas kontrol diberi perlakuan pembelajaran seperti biasanya sesuai yang digunakan di SMAN Pakusari, yaitu model contextual learning, rata-rata nilai posttest kedua kelas berbeda. Kelas eksperimen memiliki rata-rata nilai lebih besar daripada kelas kontrol. Adapun hasil anlisis independent sample T-test didapatkan nilai nilai Sig. (2tailed) pada equal variance assumed adalah
0,002 yang tergolong kurang dari 0,05. Pengambilan keputusan menyatakan bahwa nilai signifikansi kurang dari 0,05 , maka $\mathrm{H}_{0}$ ditolak dan $\mathrm{H}_{\mathrm{a}}$ diterima. Artinya, terdapat perbedaan nilai rata-rata hasil belajar siswa pada kelas eksperimen dan kelas kontrol.

Berdasarkan uraian diatas, dapat disimpulkan bahwa ada perbedaan yang signifikan antara hasil belajar siswa yang menggunakan model problem based learning (PBL) dengan media google classroom dengan model pembelajaran yang biasa digunakan di SMAN Pakusari, yaitu model pembelajaran CTL. Hal ini sesuai dengan penelitian Argaw et al. (2017: 864) yang menyatakan bahwa model PBL berpengaruh terhadap hasil belajar siswa. Pengaruh tersebut dapat disebabkan oleh beberapa faktor. Faktor-faktor tersebut, antara lain permasalahan berdasarkan kehidupan sehari-hari membuat siswa mudah memahami materi, pembelajaran berpusat pada siswa sehingga memberi siswa pengalaman langsung dalam menyelesaikan masalah, serta dengan bantuan google classroom juga membantu guru membuat waktu pembelajaran di kelas menjadi lebih efektif, mengatasi kebosanan di kelas, dan meningkatkan interaksi antara guru dan siswa. Penelitian Farisi \& Hamid (2017: 285-286) juga menyatakan bahwa dengan bantuan LKPD dapat membantu siswa dalam menyelesaikan masalah yang diberikan guru. Hal ini sesuai dengan yang dilakukan dalam penelitian yang juga menyertakan pemberian LKS kepada siswa melalui google classroom.

Berdasarkan pembahasan diatas, model problem based learning (PBL) dengan media google classroom dapat mendorong semangat belajar dan kecakapan siswa dalam menyampaikan pendapat atau bertanya, karena keaktifan siswa selama pembelajaran. Kemandirian siswa yang terbentuk juga membuat siswa terbiasa memiliki rasa ingin tahu dan terbiasa mencari jawaban dari permasalahan secara individu maupun kelompok. Dalam kelompok tersebut, kemampuan bersosial siswa menjadi meningkat, sehingga juga meningkatkan kepedulian siswa terhadap teman. Permasalahan yang berpusat pada kehidupan sehari-hari membuat siswa mudah memahami dan mengingat materi. Google classroom juga membantu guru meningkatkan efektifitas waktu pembelajaran di kelas, meningkatkan interaksi antara guru dan siswa, serta mampu mengatasi kebosanan siswa selama pembelajaran.

\section{SIMPULAN DAN SARAN}

Berdasarkan hasil penelitian dan pembahasan yang telah dilakukan maka dapat ditarik kesimpulan bahwa pembelajaran dengan 
model Problem Based Learning (PBL) dengan media google classroom berpengaruh signifikan terhadap aktivitas dan hasil belajar siswa pada materi gelombang bunyi di SMAN Pakusari.

Berdasarkan hasil penelitian dan pembahasan, maka saran yang dapat diberikan bagi guru dapat menggunakan model PBL dan media google classroom ini dalam pembelajaran fisika di sekolah dengan memberikan pengenalan atau pelatihan singkat kepada siswa tentang google classroom. Bagi peneliti lain, dalam penelitian ini masih diperlukan pengembangan model problem based learning dengan media google classroom.

\section{DAFTAR RUJUKAN}

Argaw, A. S., Haile, B. B., Ayalew, B. T., \& Kuma, S. G. (2017). The effect of problem based learning (PBL) instruction on students' motivation and problem solving skills of physics. Eurasia Journal of Mathematics, Science and Technology Education, 13(3), 857-871. https://doi.org/10.12973/eurasia.2017. 00647a

Farisi, A., \& Hamid. (2017). Pengaruh Model Pembelajaran Problem Based Learning terhadap Kemampuan Berpikir Kritis dalam Meningkatkan Hasil Belajar Ssiswa pada Konsep Suhu dan Kalor. Jurnal IImiah Mahasiswa, 2(3), 283287.

http://www.jim.unsyiah.ac.id/pendidika n-fisika/article/view/4979

Gunawan, F. I., \& Sunarman, S. G. (2017). Pengembangan Kelas Virtual Dengan Google Classroom Dalam Keterampilan Pemecahan Masalah (Problem Solving) Topik Vektor Pada Siswa Smk Untuk Mendukung Pembelajaran. Prosiding Seminar Nasional Etnomatnesia, 340-348.

Himah, E., Bektiarso, S., \& Prihandono, T. (2015). Penerapan Model Problem Based Learning $(\mathrm{Pbl})$ Disertai Metode Pictorial Riddle Dalam Pembelajaran Fisika Di Sma. Jurnal Pembelajaran Fisika, 4(3), 216-267-267.

Nofrion. (2016). Komunikasi pendidikan: Penerapan teori dan konsep komunikasi dalam pembelajaran. Kencana.

Putra, A., Bektiarso, S., \& Handayani, R. (2016). Pengaruh Model Problem Based Learning (Pbl) Terhadap Hasil Belajar Dan Keterampilan Proses Sains Dalam Pembelajaran Fisika Di Sma (Kelas X
Sma Negeri 3 Jember). Jurnal Pembelajaran Fisika Universitas Jember, 5(2), 138662.

Suardi, M. (2018). Belajar \& pembelajaran. Deepublish. 